\title{
Neurologic manifestations of AIDS: a review of fifty cases in Santos
}

Departments of Internal Medicine and of Physiology, Neurophysiology Division, Faculdade de Ciências Médicas de Santos - São Paulo, Brazil

\begin{abstract}
Objective: To review the neurologic manifestations of AIDS in patients who were admitted to Hospital Guilherme Álvaro (HGA) due to any clinical manifestation of the disease. Design: Case series. Patients: All HIV+ patients admitted to the Faculty Hospital (HGA) between July 96 and April 97 were included in this review. Results: From the $117 \mathrm{HIV}+$ patients admitted to hospitalization due to AIDS-related symptoms, 50 (42.7\%) presented neurologic manifestations. The most prevalent of these was neurotoxoplamosis (68\%), but a variety of other neurologic diseases were observed. Only $36 \%$ of these 50 patients had neurological signs and symptoms as the main complaint for admission, $12 \%$ of the patients had at least complained of some neurologic dysfunction at the time of admission and $10 \%$ had no neurologic complaints at all. The remaining $42 \%$ (21 patients) only complained of neurologic manifestations of AIDS when specifically asked. Conclusions: The prevalence of neurologic manifestations of AIDS is very high in patients admitted to hospital. Even in the absence of neurologic-related complaints, these patients have to be carefully questioned and examined in the search for an underlying neurologic complication which may present high morbidity and mortality.
\end{abstract}

UNITERMS: AIDS. HIV. Neurotoxoplasmosis.

\section{INTRODUCTION}

I $\mathrm{n}$ the past decade, clinical and laboratorial research has provided new insights into the mechanisms of acquired immunodeficiency syndrome (AIDS) and its neurologic manifestations. Early diagnosis of AIDS and efficient therapy against infections will create a forthcoming generation of AIDS patients who will live longer and may present more frequent neurologic manifestations of the disease. ${ }^{(1)}$ The human immunodeficiency virus (HIV) may infect the nervous

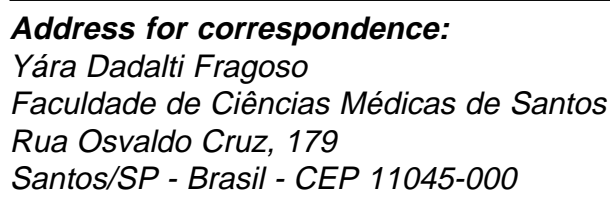

system and dementia is a frequent manifestation of such infection, ${ }^{(1,2)}$ particularly in the final stages of the disease. ${ }^{(3)}$ This neurologic complication is relatively well known by the patients, their relatives and their physicians, but it is far from being the only one in the natural course of AIDS. Together with this dementia, new neurologic syndromes have been described and AIDS has now been added to the differential diagnosis of a variety of manifestations of diseases of the nervous system. $^{(4)}$

Other major neurologic manifestations of AIDS are related to opportunistic infection. Neurotoxoplasmosis is the most frequent of such infections, with very variable prevalence: $3 \%$ to $40 \%$ of all AIDS patients. ${ }^{(1)}$ Cryptococcal meningitis, ${ }^{(5)}$ neurosyphilis, ${ }^{(6)}$ neurotuberculosis ${ }^{(7)}$ and cytomegalovirus encephalitis ${ }^{(8)}$ are also found in patients presenting neurologic manifestations of AIDS. 
The city of Santos (Brazil) is an important center for the diagnosis and treatment of AIDS in the state of São Paulo. The Faculty of Medical Sciences of Santos and its Faculty Hospital (Hospital Guilherme Álvaro) have a regular service for outpatients with AIDS and a special wing for inpatients with aggravation of symptoms. The present work is a review of 50 patients admitted into this hospital for treatment of AIDS and AIDS-related diseases, who presented some type of neurologic manifestation.

\section{METHODS}

Records from all patients admitted into the AIDS section of Hospital Guilherme Álvaro between July 1996 and April 1997 were reviewed. From the 117 patients who were admitted in this period, 50 were found to have at least one diagnosis regarding involvement of the nervous system. Age, gender, main complaint and neurologic complaint were noted, as well as diagnosis, treatment and evolution of each one of these 50 patients.

\section{RESULTS}

From the 50 patients with neurologic manifestations of AIDS, 17 were women and 33 were men. The mean age of the whole group was 35 years, the youngest being 4 years old and the oldest being 54 years old. Only 2 patients were under the age of 18 , both being female. If we do not consider the children, the mean age was 36 years. The mean age for men was 36 , and for women (excluding the 2 children) was 36 as well.

A variety of neurologic signs and symptoms were reported by the patients and their relatives. Headache, hemiparesia, paraparesia and behavioural alterations were the most frequent. Table 1 summarizes the complaints which suggested neurological dysfunction.

It is important to observe that $36 \%$ of the patients were admitted into hospital due to a specific neurological complaint. In $12 \%$ of the patients, the neurologic complaint was one of the reasons for admission, but not the only one. Neurologic signs and symptoms were detected in $42 \%$ of the patients only when they were specifically questioned or during clinical examination. In $10 \%$ of the patients, there was no evidence for neurological dysfunction either in the history or in the examination, and only during the hospitalization period was neurologic involvement considered.

The main clinical complaint of these patients admitted to hospital was diarrhea and high temperature (10 patients with infections of the gastrointestinal system); cough, weakness, weight loss and slightly raised temperature (6 cases of lung tuberculosis); pain and difficulty in swallowing (4 cases of mouth and throat moniliasis); cough and high temperature (3 patients with pneumonia). Other diagnoses included hemorrhagic syndrome, arthralgias, infected skin lesions, etc, none of them affecting more than one patient of this study.

The most frequent neurologic diagnosis was neurotoxoplasmosis (68\% of the cases). Patients with this infection fell into all the above-mentioned categories concerning neurologic signs and symptoms at the time of admission: some had focal motor deficits while others had no neurologic complaint at all. In fact, all 5 patients who did not have any neurologic signs or symptoms had neurotoxoplasmosis.

Table 2 summarizes the neurologic diagnosis of these 50 patients. Some of them had more than one infection, e.g. neurotoxoplasmosis and neurosyphilis, but more often than not, only one agent was found in the nervous system infection. Four patients presented criptococcic meningitis and one of them had neurotoxoplasmosis as well. Two patients had intercostal nerve herpes zoster and two patients who presented polyneuropathy were infected by cytomegalovirus. Seven patients had the diagnosis of HIV manifestation in the central nervous system ( 3 had dementia and 4 had polyneuropathy) and one child was diagnosed as having encephalitis, which may have been due to HIV. Two patients with neurotoxoplasmosis also referred to some degree of numbness and paresthesias of the feet, which might have been due to HIV infection. In none of the patients who entered this review was neurotuberculosis a complication of AIDS, although 6 patients had active lung tuberculosis.

Despite appropriate clinical treatment, $32 \%$ of the patients with neurologic manifestations of AIDS died while in hospital. The main reason for death was multiple organ failure due to sepsis and bad nutritional state. One patient was still in hospital at the time of this survey, one had signed his own release and another had been transferred to another hospital. Of the 31 patients who were released from hospital after treatment, 16 had shown improvement in the neurologic signs and symptoms, albeit to different degrees - this included the child with encephalitis. Eight patients with opportunistic infections leading to focal signs left hospital without clear improvement of the neurologic 
Table 1

Diagnosis of neurologic involvement in AIDS in $\mathbf{5 0}$ patients admitted to hospital

\begin{tabular}{lcc}
\hline Diagnosis & Number of patients (\%) \\
\hline Neurotoxoplasmosis & 32 & $(68 \%)$ \\
$\quad$ Criptococcic meningitis & 1 & \\
$\quad$ + Neurosyphilis & 1 & \\
Criptococcic meningitis & 3 & $(6 \%)$ \\
Herpes Zoster & 2 & $(4 \%)$ \\
Cytomegalovirus & 1 & $(2 \%)$ \\
Demential syndrome & 3 & $(6 \%)$ \\
Peripheral neuropathies & 4 & $(12 \%)$ \\
$\quad+$ cytomegalovirus & 2 & \\
Encephalitis & 1 & $(2 \%)$ \\
\hline
\end{tabular}

dysfunction. The 7 patients with HIV manifestation in the central nervous system were released without major alterations in their neurologic deficits. Two patients attempted suicide while in hospital.

\section{DISCUSSION}

Neurologic manifestations of AIDS have become more prevalent as prompt diagnosis and treatment for opportunistic infections lead to longer life. ${ }^{(9)}$ Recognition of neurologic involvement in AIDS patients is crucial for changing the quality of life and survival time for these patients. HIV can affect the nervous system at every level, opportunistic infections in the central nervous system can produce a variety of signs and symptoms, and even the treatment for these patients may provide neurologic complications. ${ }^{(1)}$ Clinicians must be attentive to the fact that AIDS patients may present myopathy due to $\mathrm{HIV}^{(10)}$ and/or the anti-viral treatment, ${ }^{(11)}$ as they can be confused, disorientated and aggressive due to HIV dementia ${ }^{(12)}$ or to psychosis related to the use of or withdrawal from illegal drugs. ${ }^{(13)}$

The prevalence of neurologic complications of AIDS in patients admitted to hospital due to this disease was of the order of $40 \%$, similar to reports in the literature from the mid 1980s onwards. ${ }^{(9,14,15)}$ The percentage of AIDS patients seeking care due to a specific neurologic complaint in our study was $15.7 \%$, while a further $5.1 \%$ sought care for a neurologic complaint plus other clinical symptoms.

The most frequent neurologic complication of AIDS in this group of 50 patients was neurotoxoplasmosis, affecting $68 \%$ of them. Though considered the most common cerebral mass lesion in patients with neurologic manifestations of AIDS, the prevalence of such opportunistic infection is no higher than $40 \%$ in the world literature $^{(1)}$ and even in other studies in Brazil. ${ }^{(16)}$ The clinical presentation of the neurotoxoplasmosis varied from focal motor signs to headache, from coma and convulsions to ataxia and spastic paraparesia. Focal signs were observed in $24 \%$ of the patients and headache in $16 \%$ of them. This finding was different to that of Porter, who recently reported that $69 \%$ of patients presenting neurotoxoplasmosis manifested focal signs and 55\% complained of headache. ${ }^{(17)}$ It was interesting to observe that 5 patients in our study who were admitted to hospital due to a variety of clinical signs and symptoms also presented "asymptomatic" neurotoxoplasmosis. In a recent Brazilian review of cases, 3 patients out of 154 had no neurologic signs or symptoms but presented lesions of the nervous system: these 3 patients had neurotoxoplasmosis. ${ }^{(16)}$

Cryptococcic meningitis is a frequent fungal infection in AIDS patients, ${ }^{(5)}$ often occurring with minimal inflammation due to the immunodeficiency. Acute symptoms of meningitis may be absent due to this subtle inflammation and, as in our four patients, headache and behavioural alterations may be the only signs of this infection. ${ }^{(18)}$

Cytomegalovirus infecting the central nervous system may cause a variety of symptoms and signs, usually similar to HIV infection itself. ${ }^{(8)}$ Other opportunistic agents may coexist with cytomegalovirus in the central nervous system and it would be difficult to be specific as to which agent was responsible for the neurologic findings. ${ }^{(8)}$ The use of the polymerase chain reaction as a routine exam to identify the presence of cytomegalovirus in the spinal fluid of AIDS patients may show that this infection is more common than we now expect it to be. ${ }^{(19)}$ In our patients, cytomegalovirus was found in one patient with cognitive and behavioural alterations who also developed cytomegalovirus retinitis, and in 2 patients with inflammatory demyelinating polyneuropathy. Cytomegalovirus may be the primary etiological agent in polyneuropathy, especially when this manifestation occurs late in the course of AIDS. ${ }^{(20)}$ If it occurs at earlier stages of the disease, and in particular at the time of seroconversion, HIV itself appears to be the agent responsible for the inflammation. ${ }^{(21)}$

Herpes zoster thoracic lesions were observed in two patients who were admitted to hospital due to other clinical complaints. There was no manifestation of zoster infection of the central nervous system in either of these patients, though one of them attempted suicide and presented hallucinations. Central nervous system infection by varicella-zoster is usually fatal, with intense vasculitis and focal lesions in the white matter. ${ }^{(22)}$ The hallucinations and 
Table 2

Main symptoms and signs of patients with neurologic involvement in AIDS (in $\mathbf{5 0}$ patients admitted to hospital). Associated symptoms are noted in brackets

\begin{tabular}{lcc}
\hline Symptoms and signs & Number of patients & Diagnosis \\
\hline $\begin{array}{l}\text { Hemiparesia } \\
\quad( \pm \text { aphasia, headache, } \\
\text { behavioural alteration) }\end{array}$ & 12 & $\mathrm{NT}(11), \mathrm{NT} / \mathrm{NCr}(1)$ \\
$\begin{array}{l}\text { Headache }( \pm \text { behavioural alteration) } \\
\text { Polyneuropathy }\end{array}$ & & \\
$\begin{array}{l}\text { Ataxia }( \pm \text { spastic paraparesia) } \\
\text { Cognitive and behavioural }\end{array} \quad \mathrm{NT}(6), \mathrm{NCr}(2)$ \\
$\quad$ alterations & 5 & $\mathrm{CMV}(2), \mathrm{HIV}-\mathrm{related}(4)$ \\
$\begin{array}{l}\text { Progressive visual loss }(+ \text { headache) } \\
\text { Herpes Zoster }\end{array}$ & 5 & $\mathrm{NT}(5)$ \\
Coma and convulsions & 2 & Dementia (3) \\
Involuntary movements and headache & 2 & NT (2) \\
Encephalitis & 2 & Herpes Zoster (2) \\
No neurologic complaints & 2 & NT (2) \\
\hline
\end{tabular}

$\mathrm{NT}=$ neurotoxoplasmosis, $\mathrm{NCr}=$ neurocriptococcosis, $\mathrm{NSy}=$ neurosyphilis, $\mathrm{CMV}=$ cytomegalovirus.

suicide attempts while in hospital were more likely due to the psychological state of the patient. ${ }^{(12,23)}$

No cases of neurotuberculosis were diagnosed in these 50 patients, despite active lung tuberculosis in $12 \%$ of them. Although described as a possible neurologic complication of AIDS, ${ }^{(7)}$ it appears to be a rather uncommon infection in these immunodeficient individuals. ${ }^{(24,25)}$

Distal symmetrical polyneuropathy is the most common form of neuropathy in HIV infection, ${ }^{(1)}$ usually progressing to a severe form of burning pain in the legs and numbness in the feet. In our review, this severe pain and difficulty in walking was the main reason for admission into hospital for two of the four patients presenting peripheral neuropathy and no other infection. It has been suggested that HIV infection of the peripheral nerve does not cause degeneration of the fibers, ${ }^{(26)}$ a condition which is possibly underdiagnosed ${ }^{(27)}$ and undertreated. ${ }^{(28)}$ The mechanism for axonal degeneration in AIDS is still unknown. ${ }^{(1)}$

An interesting finding in the present review was the incidence of headache in these 50 patients: $40 \%$ of them complained of headache with or without other neurologic symptoms and signs. Although no large scale epidemiological study on the prevalence of headache in AIDS patients has ever been undertaken, it is generally accepted that HIV-infected individuals have a higher prevalence of headache than the general population. ${ }^{(29)}$ These patients may have headache due to primary causes (e.g., migraine and tension type headache), drug abuse and withdrawal, mass lesions and infections of the central nervous system, and/or due to antiviral drugs and antibiotics. ${ }^{(29,30)}$ AIDS patients presenting headache must be carefully investigated in order to improve duration and quality of life. ${ }^{(30)}$

Although myopathy has been described as a relatively common complication in AIDS, ${ }^{(1)}$ it was not diagnosed in any of the 50 patients here reviewed. However, the wasting syndrome often observed in AIDS patients may be the only clinical feature of this myopathy, ${ }^{(31)}$ and therefore this complication may be underdiagnosed.

HIV dementia is a frequent complication of AIDS and may be underestimated in the early stages. ${ }^{(32)}$ Three patients in our study presented dementia in advanced stages of behavioural and cognitive alterations, apathy with crises of aggressivity, psychomotor retardation and abnormal gait. HIV dementia is a diagnostic of exclusion, and the brain lesions are often less prominent than their clinical symptoms would predict. ${ }^{(1,2)}$ Subtle neurologic signs and psychomotor evaluation must be routinely investigated in HIV+ individuals because the neurologic deficits usually progress insidiously. ${ }^{(33,34)}$ Systemic illnesses and previous neuropsychologic impairment due to drug abuse have to be considered when evaluating subclinical cases of dementia. ${ }^{(35)}$

\section{CONCLUSION}

Neurologic manifestations in AIDS are frequent complications which may affect every level of the nervous system. In the present review, we observed that a variety 
of neurological symptoms and signs lead these HIV+ patients to seek medical care and hospitalization. Patients in Santos had similar incidence of neurologic manifestations of AIDS to that reported in the literature, but a much higher incidence of neurotoxoplasmosis. Clinical awareness of potential neurologic complications of this immunodeficiency is a crucial path to reducing morbidity and mortality of these patients.

\section{Resumo}

Objetivo: Revisão das manifestações neurológicas de SIDA em pacientes admitidos no Hospital Guilherme Álvaro (HGA) devido a manifestações clínicas da doença. Tipo de estudo: Série de casos. Pacientes: Todos os pacientes HIV+ admitidos no Hospital da Faculdade (HGA) entre julho de 1996 e abril de 1997 foram incluídos nesta revisão. Resultados: Do total de 117 pacientes HIV+ admitidos para hospitalização por piora da sintomatologia de AIDS, 50 $(42.7 \%)$ apresentavam manifestações neurológicas. A mais prevalente destas foi neurotoxoplasmose (68\%), mas uma variedade de outras doenças neurológicas foi observada. Apenas 36\% destes 50 pacientes apresentavam sinais e sintomas neurológicos como queixa principal na internação, 12\% relatavam alguma disfunção neurológica entre suas queixas e $10 \%$ não apresentavam qualquer queixa neurológica mesmo quando questionados. Os demais 21 pacientes (42\%) apenas mencionaram manifestações neurológicas quando especificamente interrogados na anamnese. Conclusões: A prevalência de manifestações neurológicas de SIDA foi bastante alta nos pacientes admitidos no hospital. Mesmo na ausência de queixas de disfunção do sistema nervoso, pacientes HIV+ devem ser sistematicamente interrogados e examinados em busca de alguma intercorrência neurológica com grande potencial de morbidade e mortalidade se não diagnosticada e tratada.

\section{REFERENCES}

1. Simpson DM, Tagliati M. Neurologic manifestations of HIV infection. Ann Inter Med 1994; 121:769-85.

2. Navia BA, Jordan BD, Price RW. The AIDS dementia complex: I. Clinical features. Curr Opin Psychiatry 1990; 3:96-102.

3. Newton HB. Common neurologic complications of HIV-1 infection and AIDS. Amer Fam Physician 1995; 51 (2):387-98.

4. Richman DP. Neurology of human immunodeficiency virus: past, present and future. Neurology 1995; 163:470-1.

5. Dismukes WE. Cryptococcic meningitis in patients with AIDS. J Infect Dis 1988; 157:624-8.

6. Musher, DM. Syphilis, neurosyphilis, penicillin and AIDS. J Infect Dis 1991; 163:1201-6.

7. Bishburg E, Sunderam G, Reichman LB, Kapila R. Central nervous system tuberculosis with the acquired immunodeficiency syndrome and its related complex. Ann Intern Med 1986; 105:210-3.

8. Morgello S, Cho ES, Nielsen S, Devinsky O, Petito CK. Cytomegalovirus encephalitis in patients with acquired immunodeficiency syndrome: an autopsy study of 30 cases and a review of the literature. Hum Pathol 1987; 18:289-97.

9. Bacellar H, Munoz A, Miller EN, Cohen BA, Besley D, Selnes OA, Becker JT, McArthur JC. Temporal trends in the incidence of HIV-related neurologic diseases: multicenter AIDS cohort study. Neurology 1994; 44:1892-900.
10. Simpson DM, Bender AN. Human immunodeficieny virusassociated myopathy: analysis of 11 cases. Ann Neurol 1988; 24:79-84.

11. Dalakas MC, Illa I, Pezeshkpour GH, Laukaitis JP, Cohen B, Griffin JL. Mitochondrial myopathy caused by long-term zidovudine therapy. N Engl J Med 1990; 322:1098-105.

12. Evans DL, Perkins DO. The clinical psychiatry of AIDS. Curr Opin Psychiatry 1990;3:96-102.

13. Grassi MP, Perin C, Clerici F, Zocchetti C, Borella M, Cargnel A, Mangoni A. Effects of HIV seropositivity and drug abuse on cognitive function. Eur Neurol 1997;37:48-52.

14. Levy RM, Rosenblum ML. Neurological manifestations of the acquired immunodeficiency syndrome (AIDS): experience at UCSF and review of the literature. J Neurosurg 1985;62:475-95.

15. MacArthur JC. Neurologic manifestations of AIDS. Medicine 1987;66:407-37.

16. Camara VD, Tavares W, Rocha MPR, Chimelli LC, DumasHahn M. Contribuição ao conhecimento das alterações neurológicas em pacientes com SIDA. Arq Neuropsiquiatr 1995;53(1):53-9.

17. Porter SB, Sande MA. Toxoplasmosis of the central nervous system in the acquired immunodeficiency syndrome. N Engl J Med 1992;327:1643-8.

18. Powderly WG. Cryptococcal meningitis and AIDS. Clin Infect Dis 1993; 17:837-42.

19. Clifford DB, Buller RS, Mohammed S, Robinson L, Storch GA. Use of polymerase chain reaction to demonstrate 
cytomegalovirus DNA in CSF of patients with human immunodeficiency virus infection. Neurology 1993;43:75-9.

20. Morgello S, Simpson DM. Multifocal cytomegalovirus demyelinative polyneuropathy associated with AIDS. Muscle Nerve 1994;17:176-82.

21. So YT, Olney RK. Acute lumbosacral polyradiculopathy in acquired immunodeficiency syndrome: experience in 23 patients. Ann Neurol 1994;35:53-8.

22. Morgello S, Block GA, Price RW, Petito CK. Varicella-zoster virus leukoencephalitis and cerebral vasculopathy. Arch Patol Lab Med 1988;112:173-7.

23. Cote TR, Biggar RJ, Dannenberg AL. Risk of suicide among persons with AIDS: a national assessment. JAMA 1992;268:2066-8.

24. Hollander H, McGuire D, Burack JH. Diagnostic lumbar puncture in HIV-infected individuals: analysis of 138 cases. Ann J Med 1994;96:223-8.

25. Friedmann PD, Samore MH, Kraemer KL, Calkins DR. Clinical correlates of secondary meningitis in HIV-infected adults. Arch Intern Med 1995;155:2231-7.

26. Mah V, Vartavarian LM, Akers MA, Vinters HV. Abnormalities of peripheral nerve in patients with human immunodeficiency virus infection. Ann Neurol 1988;24:713-7.

27. So YT, Holtzman DM, Abrams DI, Olney RK. Peripheral neuropathy associated with acquired immunodeficiency syndrome: prevalence and clinical features from a population-based survey. Arch Neurol 1988;45:945-8.
28. Breibart W, Rosenfeld BD, Passik SD, McDonald MV, Thaler H, Portenoy RK. The undertreatment of pain in AIDS ambulatory patients. Pain 1996;65:243-9.

29. Holloway RG, Kieburtz KD. Headache and the human immunodeficiency virus type-I infection. Headache 1995;35:245-55.

30. Lipton RB, Feraru ER, Weiss G, Chhabria M, Harris C, Aronow H, Newman LC, Solomon S. Headache in HIV-1 related disorders. Headache 1991;31:518-22.

31. Simpson DM, Bender AN, Farraye J, Mendelson SG, Wolfe DE. Human immunodeficiency virus wasting syndrome may represent a treatable myopathy. Neurology 1990; 40(3):535-8.

32. Siditis JJ, Price RW. Early HIV-1 infection and the AIDS dementia complex. Neurology 1990;40:323-6.

33. Sacktor NC, Bacellar H, Hoover DR, Nance-Sproson TE, Selnes OA, Miller EN, DalPan GJ, Kleeberger C, Brown A, Saah A, McArthur JC. Psychomotor slowing in HIV infection: a predictor of dementia, AIDS and death. J Neurovirol 1996;2:404-10.

34. Selnes OA, Galai N, McArthur JC, Cohn S, Royal 3rd W, Esposito D, Vlahov D. HIV infection and cognition in intravenous drug users: long-term follow-up. Neurology 1997;48:223-30.

35. Lopez OL, Becker JT, Banks G, Giconi J, Sanchez J, Dorst SK. Development of subtle neurological signs after systemic illness in HIV-infected individuals. Eur Neurol 1996;36:71-5. 